\title{
Study on the Strategy against Negative Transfer on Lexical Level in C-E Translation Teaching among English-Majoring Students --Based on Presentation Teaching Method
}

\author{
Wei Liu ${ }^{1, a}$ \\ ${ }^{1}$ Foreign Language College, NanChang Normal University, Nanchang, Jiangxi Province, China \\ aliuweicynthia@163.com
}

Keywords: Negative transfer; collocative meaning; connotative meaning; C-E translation teaching.

\begin{abstract}
Negative Transfer has always been the focus of translation teaching. This article sets off exploring the method against negative transfer on lexical level in the course of C-E translation by adopting Presentation Teaching Method. Through teaching experiment, it was discovered that giving presentations could help students improve their understanding of disparities between the collocative meaning and connotative meaning of phrases and boost their phrase storage, which, through long-time practice, could add to their translation competence.
\end{abstract}

\section{Introduction}

Nearly a century, language transfer has become an important topic in Applied Linguistics and Second Language Acquisition (SLA). Many scholars have paid attention to it. They also explore the influences of language transfer on SLA and its functions in perspective of psychology, language and society. Krashen, an American linguist, proposed that transfer is a phenomenon, that is, during the process of SLA, learners ask help for their knowledge of native language instead of the target language, which is caused by the lack of knowledge of the target language.[1] In perspective of psychology, Faerch and Kasper proposed that language is a linguistic psychological process, that is, a second language learner promotes his interlanguage through his knowledge of native language. [2] In perspective of cognitive linguistics, Schachter, a linguist, proposed that transfer is a kind of constraint in language learning, that is, a learner's knowledge of native language may have constraints while making assumptions of the target language. [3] Regardless of the different opinions, they all stressed the influence of native language on target language while learning second language. In terms of these influences, transfer can be divided into "positive transfer" and "negative transfer". The positive influence is positive transfer while the negative influence is negative transfer. [4] In the recent century, with the development of language transfer in SLA, the scholars engage in translation also begin to focus on it. At present, most of the researches on language transfer at home explore the reflections of language transfer in translation, that is, lexical level, syntax level and discourse level. Some researchers deeply investigated into the interference of language transfer on learners' lexical and syntax learning. [5] (PAN Jin, 2009) And it was proposed that in the three levels of negative transfer, lexical transfer is the most common, as well as the most perceive and remedial (ZHANG Qian, 2009). According to linguist Leech's semantic meaning classification (1970) [6], namely, conceptual meaning, connotative meaning, social meaning, affective meaning, reflected meaning, collocative meaning, thematic meaning, some researchers found that the confusion of conceptual meaning, connotative meaning and collocative meaning, the misuse of lexical transfer are quite common. And in the three kinds of meanings, the language transfer of collocative meaning is the most common, followed by connotative meaning and conceptual meaning. [7] (ZHANG Qian, 2009; PAN Jin, 2009) However, at present, the empirical research on overcoming the negative language transfer at lexical level has not been carried out. Therefore, this study adopts the presentation teaching method to present vocabulary translation, enhance the students' understanding of the differences between English and Chinese vocabularies and improve their vocabulary translation level. 


\section{Introduction of Presentation Theory}

Presentation pedagogy as an effective approach of constructivist teaching theory, which helps to enhance the language learners' capacity to use language in real situations, mobilize their learning interest and motivation, enhance classroom activity and make learning more live, colorful and effective. Thus, it is widely used both at home and abroad. In the constructivist theory, "For learners, learning is not simply transfer and convey the knowledge from outside to inside, but the process of actively constructing their own knowledge and experience. It is not the knowledge transfer process by teachers, but the process of constructing knowledge by learners themselves. Learners do not passively absorb information, but actively construct the meaning of information, which cannot be replaced by someone else. [8] The teachers are sages on the stage before, but now they guide on the side. They were imparters before, but now they are guiders, guiding the students to discover and explore. At present, translation course for English majoring students are generally offered when they are seniors, two lessons per week. E-C translation is in the first semester and C-E translation is in the second semester. Due to the limited lessons, the teaching contents are mainly translation methods and skills, and the differences between English and Chinese mindset. At the end of the course, the students often have some plain understanding of translation methods and the ways to deal with sentence structures. When it comes to vocabulary translation, they often translate it literally and translate one by one. This greatly affected their translation quality and level. The presentation teaching method could increase the students' translation interests, encourage the students to collect the unequal C-E vocabulary translations actively, which helps to strengthen their awareness of the differences of E-C vocabulary translation and improve their translation level.

\section{Research Methodology}

Participants. English majoring students in Class 2 and Class 3 of School of Foreign Studies participated in this experiment. They all attended the college entrance examination. There is no significant difference in the number of participants and their scores. Class 3 is the experimental group with 40 participants. Class 2 is the control group with 45 participants.

Instruments. Both qualitative and quantitative analyses were adopted in this experiment. Class 2 and Class 3 participated in the pre-test. It was a paragraph translation of C-E, whose difficulty was similar to CET 6. This test was limited in 30 minutes and scored with the standards of CET 6 . The results were analyzed by SPSS 19.0 and independent sample t Test was adopted. The results were shown in Table 1.

Table 1

\begin{tabular}{|l|l|l|c|c|}
\hline Class & Mean & SD & T & Sig.(2-tailed) \\
\cline { 1 - 3 } $3(40)$ & 69.315 & 13.283 & \multirow{2}{*}{0.042} & 0.532 \\
\cline { 1 - 3 } $2(45)$ & 68.647 & 14.109 & & \\
\hline
\end{tabular}

As shown in the results, there was no significant difference in the values of mean in two classes $(t=0.042, p=0.532>0.05)$. Therefore, there was no significant difference in the participants' translation abilities in two classes.

Research Design. Organization forms of presentation teaching method. The form of grouping is the most form in presentation teaching method. To increase the participants' enthusiasm and promote their communication, this experiment divided the participants into 13 groups. There were three or four participants in each group. This classification was mainly based on their scores, which was divided into three levels, good, medium and poor. Meanwhile, to ensure the obvious topic and abundant content in class, we set up the presentation content, which was classified into four parts, noun phrases, verb phrases, adjective phrases and adverb phrases. The participants in each group gain the information through books, internet, or parallel corpus. Then, they chose research subject and collected the phrases with different collocative meaning and connotative meaning. Finally, they made 
PowerPoint and presented their results within five to seven minutes. During the presentation, the participants were encouraged to ask questions about the presentation content, which helped to promote their initiative and reflective capability. For instance, a participant's presentation was on Chinese and English Expressions of "hei (black)". In English, "dark horse", instead of "black horse" refers to "hei ma" in Chinese. Another participant proposed that what "hai qun zhi ma (black sheep)" is in English. These sporadic questions were great challenges for the other participants and teachers. Therefore, the teachers would help to answer if necessary. On the other hand, this process would gradually improve students' divergent thinking and the learning method of analogy.

Another participant presented an adjective, "feng hua zheng mao". "feng hua" refers to brilliance. "mao" refers to thick and dense. But in this phrase, "mao" refers to exuberant. And this phrase refers to someone is exuberant, attractive and talented, which is the best period in his life. If we correspond with the Chinese characters one by one, the translation would be "thick/great brilliance", which is really unacceptable. The participants could make the best use of internet resources and online parallel corpus (for instance, the commonly used bilingual corpus of Xiamen University, www.luweixmu.com/ec-corpus/query.asp), and search the Chinese phrases. By comparing the expression differences between English and Chinese vocabularies, they could further understand the differences between English and Chinese, which contributes to their translation improvement.

Assessment forms of presentation teaching method. To ensure the quality of Presentation, we encouraged the participants to assess from pronounce, content and effectiveness. The full mark of each item is 100 . The mean of three items is a participant's presentation score.

Meanwhile, to ensure the participants' participation and their absorption of presentation contents, we carried out short-term and long-term vocabulary tests, including spoken and written tests. The spoken test was after the presentation, which required the participants answer questions on the involved vocabularies with no reference. To guarantee the justice of tests, the vocabularies were randomly chosen by the teacher. The written test was at the end of each month. Twenty to twenty-five vocabularies in the latest month were chosen. While the teacher read words in Chinese, the students should translate them into English.

\section{Results and Discussions}

In the 16th week of our experiment, we did post test among the participants in experimental group and control group. The test included the translation of fifteen sentences. Each of the sentences has the same word, which aims to explore the translation difference of a word in different contexts and collocations. The test was limited with 60 minutes. Independent sample t Test was adopted to compare the results of two groups by SPSS 19.0. The results were shown in Table 2.

Table 2

\begin{tabular}{|c|c|c|c|c|}
\hline Class & Mean & SD & T & Sig.(2-tailed) \\
\cline { 1 - 3 } $3(40)$ & 76.529 & 10.115 & \multirow{2}{*}{2.542} & 0.034 \\
\cline { 1 - 3 } $2(45)$ & 71.846 & 13.322 & & \\
\hline
\end{tabular}

We can see that the values of mean are significantly different $(t=2.542, p=0.034<0.05)$. Meanwhile, to ensure the reliability of experiment and collect the participants' feedback, the author designed a questionnaire on the participants' translation habits and practice frequency, as well as their satisfaction of translation teaching experiment. 40 pieces questionnaires were sent and collected. The results (expect the open questions) were shown in Table 3. 
Table 3

\begin{tabular}{|c|c|c|c|c|}
\hline $\begin{array}{c}\text { The understanding of } \\
\text { collocative differences of E-C } \\
\text { vocabularies after receiving } \\
\text { presentation teaching }\end{array}$ & $\begin{array}{c}\text { No } \\
\text { improvement } \\
2 \%\end{array}$ & $\begin{array}{c}\text { A little } \\
\text { improvement } \\
76 \%\end{array}$ & $\begin{array}{c}\text { Improved } \\
18 \%\end{array}$ & $\begin{array}{c}\text { Greatly } \\
\text { improved } \\
4 \%\end{array}$ \\
\hline $\begin{array}{l}\text { The understanding of } \\
\text { connotative differences of } \\
\text { E-C vocabularies after } \\
\text { receiving presentation } \\
\text { teaching }\end{array}$ & $\begin{array}{c}\text { No } \\
\text { improvement } \\
4 \%\end{array}$ & $\begin{array}{c}\text { A little } \\
\text { improvement } \\
78 \%\end{array}$ & $\begin{array}{c}\text { Improved } \\
14 \%\end{array}$ & $\begin{array}{c}\text { Greatly } \\
\text { improved } \\
4 \%\end{array}$ \\
\hline $\begin{array}{c}\text { The understanding of } \\
\text { vocabulary translation after } \\
\text { receiving presentation } \\
\text { teaching }\end{array}$ & $\begin{array}{c}\text { No } \\
\text { improvement } \\
0 \%\end{array}$ & $\begin{array}{c}\text { A little } \\
\text { improvement } \\
66 \%\end{array}$ & $\begin{array}{c}\text { Improved } \\
30 \%\end{array}$ & $\begin{array}{c}\text { Greatly } \\
\text { improved } \\
4 \%\end{array}$ \\
\hline $\begin{array}{l}\text { The accumulation of C-E } \\
\text { translation vocabularies after } \\
\text { receiving presentation } \\
\text { teaching }\end{array}$ & $\begin{array}{c}\text { No } \\
\text { improvement } \\
2 \%\end{array}$ & $\begin{array}{c}\text { A little } \\
\text { improvement } \\
43 \%\end{array}$ & $\begin{array}{c}\text { Improved } \\
47 \%\end{array}$ & $\begin{array}{l}\text { Greatly } \\
\text { improved } \\
8 \%\end{array}$ \\
\hline $\begin{array}{l}\text { The understanding of cultural } \\
\text { differences between English } \\
\text { and Chinese after receiving } \\
\text { presentation teaching }\end{array}$ & $\begin{array}{c}\text { No } \\
\text { improvement } \\
14 \%\end{array}$ & $\begin{array}{c}\text { A little } \\
\text { improvement } \\
58 \%\end{array}$ & $\begin{array}{c}\text { Improved } \\
26 \%\end{array}$ & $\begin{array}{l}\text { Greatly } \\
\text { improved } \\
2 \%\end{array}$ \\
\hline $\begin{array}{l}\text { The interest of translation } \\
\text { after receiving presentation } \\
\text { teaching }\end{array}$ & $\begin{array}{c}\text { No } \\
\text { improvement } \\
\text { 8\% }\end{array}$ & $\begin{array}{c}\text { A little } \\
\text { improvement } \\
56 \%\end{array}$ & $\begin{array}{c}\text { Improved } \\
28 \%\end{array}$ & $\begin{array}{l}\text { Greatly } \\
\text { improved } \\
8 \%\end{array}$ \\
\hline $\begin{array}{c}\text { The improvement of } \\
\text { self-confidence of English } \\
\text { translation after receiving } \\
\text { presentation teaching }\end{array}$ & $\begin{array}{c}\text { No } \\
\text { improvement } \\
38 \%\end{array}$ & $\begin{array}{c}\text { A little } \\
\text { improvement } \\
50 \%\end{array}$ & $\begin{array}{c}\text { Improved } \\
12 \%\end{array}$ & $\begin{array}{c}\text { Greatly } \\
\text { improved } \\
0 \%\end{array}$ \\
\hline
\end{tabular}

Obviously, the participants all speak highly of presentation teaching method. After this experiment, their understanding of collocative and connotative differences of $\mathrm{E}-\mathrm{C}$ vocabularies has been improved. $76 \%$ of the participants thought that presentation teaching method helped to greatly improve their understanding of E-C vocabulary translation. 18\% of the participants thought their understanding of E-C vocabulary translation has been improved. Only $2 \%$ of the participants thought their understanding has not been improved. At the same time, presentation teaching method has also greatly increased the participants; translation interest. $56 \%$ of the participants thought that presentation teaching method helped to greatly increase their understanding and interest of translation. Only $8 \%$ of them supposed thought it was almost useless. Some participants began to collect the English expressions four weeks after the presentation. Meanwhile, presentation teaching method required higher autonomous learning ability. However, we can see that presentation teaching method was almost not helpful to improve their self-confidence of translation. None of them thought their self-confidence was greatly improved. This showed that the improvement of translation did not only 
depend on their vocabularies. The comprehensive improvement of syntax and discourse might be helpful.

On the other hand, presentation teaching method also showed the participants' weakness. During their presentation, we found that most of them prefer the topic of collocation instead of connotation. In one class, 32 of the total 40 participants chose the topic of collocation. Only 8 of them chose the topic of connotation. This was mainly because of the abundant resources of collocation on the internet and books. In addition, the participants have not paid much attention to connotative meaning. In the future translation teaching, we could enhance students' vocabulary translation and improve their comprehensive translation ability through current teaching resources and internet resources.

\section{Conclusions}

As proved in this experiment, Presentation Teaching Method contributes to students' vocabulary, improves their interests of translation, helps to better understand the cultural differences between English and Chinese and increases their divergent and associative thinking, as well as greatly improves their self-confidence. Although the students negatively collect translation vocabularies at first, they positively think about the daily expressions and discuss with each other and adopt some modern approaches to explore the answers. Therefore, proper and effective teaching methods would greatly promote the vocabulary teaching of E-C translation.

\section{Acknowledgement}

Fund Project: This paper presents the ultimate research outcomes of a project supported by Foreign Language College, Nan Chang Normal University, The Application of Presentation Teaching Method in Translation Teaching among English-majoring Students.

\section{References}

[1] Krashen, stephen and Tracy Terrell. The Natural Approach[M]. Oxford: Pergamon/Alemany Press, 1983

[2] Schachter, Jacquelyn. An error in error analysis[J].Language Learning, 1974, (24): 205-14.

[3] Faerch, C. and G. Kasper. Two ways of defining communication strategies. [J]Language learning: A journal of applied linguistics, 1984.

[4] YU Shanmu. Transfer in Foreign Language Learning [J]. Foreign Language Teaching and Research, 1986, (4): 41-46.

[5] PAN Jin. An Empirical Study on Native Language Transfer in C-E Translation [D]. Hunan: Hunan University of Science and Technology, 2009.

[6] Leech, Geoffrey N. Towards a Senmantic Description of English. [M]. Bloomington: Indiana University Press. 1970.

[7] ZHANG Qian. Negative Transfer of Native Language in Perspective of Vocabulary - An Empirical Study among English Majoring Students in Xi'an International Studies University [D]. Central South University, 2009.

[8] CHEN Qi. Contemporary Educational Psychology [M]. Beijing Normal University Publishing Press. 2007. 